\title{
Application of the E-Bussines Concept to a Double Bread Company (Case Study of FEBI UINSU Students)
}

\section{Penerapan Konsep E-Bussines pada Perusahaan Roti Ganda (Studi Kasus Mahasiswa FEBI UINSU)}

\author{
Arbarija Hafiz Lbs 1); Erlangga Hakim Manurung 2); Nurbaiti2) \\ 1,2) Universitas Islam Negeri Sumatera Utara \\ Email: ${ }^{1)}$ arbarijah@gmail.com; ${ }^{2)}$ erlanggahakim75@gmail.com; ${ }^{2)}$ nurbaiti@uinsu.ac.id
}

\section{How to Cite :}

Lbs, A. H., Manurung, E. H., Nurbaiti. (2022). Application of the E-Bussines Concept to a Double Bread Company (Case Study of FEBI UINSU Students). Jurnal Ekonomi Manajemen Akuntansi Dan Keuangan, 3(1). DOI: https://doi.org/10.53697/emak.v3i1

ARTICLE HISTORY

Received [22 Desember 2021]

Revised [29 Desember 2021]

Accepted [05 Januari 2022]

\section{KEYWORDS}

Company, E-Business

Implementation, E-commerce,

Double Bread

This is an open access article under the $C C-B Y$-SA license

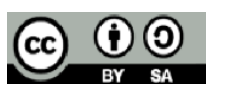

\section{ABSTRAK}

Dengan banyaknya peminat Roti Ganda diluar daerah Pematang Siantar, maka dari itu diperlukannya sistem penerapan E-business pada perusahaan. Penggunaan teknologi e- business mempermudah kinerja perusahaan dan meningkatkan kualitas perusahaan. Penerapan teknologi ini dapat memperluas pangsa pasar perusahaan terutama adalah biaya untuk iklan yang murah dibandingkan dengan iklan di jalan maupun media massa. Perlu adanya sosialisasi dan pembelajaran yang mendalam serta persiapan yang matang sebelum menerapkan aplikasi e- business. Dalam proses perancangan Penerapan E-Business pada Toko Roti Ganda berbasis web dengan pendekatan CRM (Customer Relationship Management) diperlukan penjelasan atau teori yang dapat mendukung dan menunjang keberhasilan dalam pembuatan sistem informasi tersebut serta untuk menjelaskan kepada user bagaimana fungsi dan manfaat dari penerapan E- Business pada Toko Roti Ganda berbasis web dengan pendekatan CRM.

\section{ABSTRACT}

With the large number of fans of Roti Ganda outside the Pematang Siantar area, therefore an E-business implementation system is needed in the company. The use of e-business technology facilitates company performance and improves company quality. The application of this technology can expand the company's market share, especially the cost for advertising which is cheap compared to advertising on the street and mass media. There needs to be socialization and in-depth learning as well as careful preparation before implementing e-business applications. In the process of designing the application of E-Business at a web-based Double Bakery Shop with a CRM (Customer Relationship Management) approach, an explanation or theory is needed that can support and support success in making the information system and to explain to users how the functions and benefits of implementing E-Business are needed. on a webbased Double Bakery with a CRM approach.

\section{PENDAHULUAN}

E-business pertama kali diperkenalkan oleh Lou Gerstner, CEO perusahaan IBM. Istilah tersebut, dapat diterjemahkan sebagai kegiatan bisnis yang dilakukan secara otomatis dan semi 
otomatis dengan menggunakan sistem informasi komputer. E-business memungkinkan suatu perusahaan untuk berhubungan dengan sistem pemrosesan data internal dan eksternal mereka secara lebih efisien dan fleksibel. Di dunia global saat ini perusahaan harus mampu berevolusi dan menyesuaikan diri dengan kebutuhan bisnis baik akan informasi maupun teknologi. Walupun penerapan e-business di Indonesia belum terbilang marak namun penelitian yang dilakukan oleh Warta Ekonomi memperlihatkan bahwa 54.2\% perusahaan yang menjadi responden sudah menerapkan berbagai aplikasi e-business, diantaranya: Enterprise Resource

Planning (ERP), Supply Chain Management (SCM), dan Customer Relationship Management (CRM). Sebanyak $78.8 \%$ perusahaan yang menjadisample dalam penelitian tersebut menyatakan bahwa pemanfaatan solusi e-business dapat meningkatkan produktivitas perusahaan. Selain itu, perkembangan pasar yang mulai menjadi global membuat setiap perusahaan harus mampu melayani pasar global tersebut. Saat ini jarak dan lokasi pasar bukanlah permasalahan yang fundamental lagi namun, saat ini permasalahannya adalah bagaimana perusahaan agar bisa dan mampu menarik dan melayani konsumen sebanyak mungkin tidak peduli lokasi dan jarak yang ada.

Toko Roti Ganda di Pematangsiantar meupakan toko roti yang telah lama berdiri dan masih menjadi primadona di kota tersebut. Sejak tahun 1972 toko roti tersebut telah berdiri dan tetap menjaga cita rasanya sampai sekarang sehingga pelanggan dari toko roti ini tetap loyal dalam mengkonsumsi rotinya. Beberapa roti yang dijual adalah roti tawar, roti kelapa, bolu, kue lapis Surabaya dan lapis legit. Namun roti tawar yang ada pada Toko Roti Ganda ini adalah produk unggulan yang menjadi andalah toko roti tersebut. Bahkan banyak perantau yang bekerja di luar kota menjadikan roti ini sebagai oleh - oleh khas dari kota Pematangsiantar. Hal - hal yang membuat pelanggan toko roti ini dapat loyal dalam membeli dan mengkonsumsi roti ini adalah kebersihan dan cita rasa yang terus di pertahankan oleh toko roti ini juga membuat masyarakat percaya dan loyal.

Dengan banyaknya peminat Roti Ganda diluar daerah Pematang Siantar, maka dari itu diperlukannya sistem penerapan E-business pada perusahaan tersebut. Serta Berdasarkan uraian yang telah diuraikan diatas, penulis tertarik untuk mengkaji bagaimana peran E-business pada Perusahaan Roti Ganda..

\section{LANDASAN TEORI}

\section{E-business}

Istilah E-business mengacu pada penggunaan internet untuk berdagang. Adanya kesamaan terminologi dengan e-mail, e-commerce, karena sama- sama menggunakan internet.Istilah yang lebih umum dibanding e-commerce, tidak hanya pada pembelian dan penjualan, tetapi juga pada pelayanan pelanggan dan bekerja dengan mitra bisnis. Pengertian paling sederhana, e-business adalah penggunaan teknologi internet untuk meningkatkan dan mengubah bentuk proses bisnis utama. Kebanyakan perusahaan sudah mulai banyak berkembang dari praktik bisnis tradisional ke e-business.

Penggunaan teknologi e- business mempermudah kinerja perusahaan dan meningkatkan kualitas perusahaan. Penerapan teknologi ini dapat memperluas pangsa pasar perusahaan terutama adalah biaya untuk iklan yang murah dibandingkan dengan iklan di jalan maupun media massa. Perlu adanya sosialisasi dan pembelajaran yang mendalam serta persiapan yang matang sebelum menerapkan aplikasi e- business.Kelemahan pada e-businessdapat disiasati dengan cermat, namun dibutuhkan lebih dari sekedar rencana yang matang, juga tenaga ahli yang menanganinya. Perusahaan yang tidak mau beralih ke teknologi ini, lambat laun akan kewalahan menghadapi era pasar terbuka nantinya.

\section{Aplikasi E-business}

Macam-macam aplikasi e-business menurut Indrajit (2002:20) yaitu : 
1. Customer Relationship Management (CRM) : Sistem kustomisasi real time yang memanajemen customer dan melakukan personalisasi produk dan servis berdasarkan keinginan customer atau menyangkut hubungan antara perusahaan dengan konsumen yang meliputi pemasaran, data-data penjualan dan pelayanan, anggapan dari konsumen.

2. Enterprise Resource Planning (ERP): Sistem informasi pendukung e- business, yang menyediakan berbagai macam kebutuhan perusahaan seperti supply chain, customer relation marketing, marketing, warehouse, shipping, dan payment, serta mampu melakukan otomatisasi proses bisnis atau menyangkut hubungan dalam internal perusahaan tersebut, yang meliputi: Production Planning, Integrated Logistics, Accounting and Finance, Human Resource, Sales and Distribution, Order Management.

3. Enterprise AplicationProgram (EAI) : Merupakan konsep integrasi berbagai proses bisnis dengan memperbolehkan mereka saling bertukar data berbasis message. EAl berfungsi sebagai penghubung ERP dengan SCM atau ERP dengan CRM.

4. Supply Chain Management (SCM) : Manajemen rantai supply secara otomatis terkomputerisasi. SCM menyangkut hubungan antara perusahaan dengan supplier.

\section{Ruang lingkup e-business}

Perusahaan dikatakan memiliki keunggulan kompetitif jika sanggup menjadi pemimpin pasar dibandingkan dengan pesaing lainnya di industri yang relatif sama. Ditinjau dari aspek kepada pelanggan, peusahaan berhasil menciptakan sebuah pendekatan baru dan unik didalam mengelola komunikasi dan interaksi dengan pelangganannya.

Tujuan dari pendekatan ini adalah untuk mendapatkan sebuah suasana yang intim dan akrab dengan pelanggan, sehingga konsumen selalu loyal dengan peusahaan tersebut. Customer Relationship Management meupakan aspek penting yang harus selalu dipehatikan perusahan. Selain itu kecepatan penciptaan produk baud an kecepatan pengirimannya ke tangan pelanggan juga menjadi kriteria utama yang menjadi bahan pertimbangan posisi perusahaan didunia persaingan. Semakin cepat pelanggan dapat memperoleh suatu produk pesanannya, semakin baik. Dan tentu saja perusahaan akan berhasil mencapai kondisi ini jika manajemen rantai pasokannya terkelola secara optimal.

Dampak Positif dan Negatif dari E-business

Adapun beberapa dampak positif dari e-business di antaranya :

1. Akses yang mudah

2. Lebih tepat sasaran

3. Menghemat waktu

4. Tidak membutuhkan modal yang terlalu besar

Adapun beberapa negatif yang dimiliki oleh e-business di antaranya:

1. Tidak adanya pertemuan secara langsung

2. Beresiko terjadinya penipuan

3. Pencurian informasi

4. Kehilangan kesempatan bisnis

5. Kehilangan finansial

6. Penggunaan akses oleh orang yang tidak bertanggung jawab (Hacker)

7. Kehilangan kepercayaandari konsumen

\section{Konsep E-business}

Teknologi informasi dan komunikasi adalah komponen yang sangat penting dalam proses bisnis, baik barang maupun jasa dalam meraih keunggulankompetitif. Teknologi informasi dan komunikasi mengubah cara orang bekerja (the way people work) sekaligus mengubah cara perusahaan bersaing (the way business compete). Dukungan teknologi informasi dan komunikasi mengembangkan cara baru dalam bertransaksi (e-commerce). 


\section{Manfaat E-business}

Beberapa manfaat yang bisa di dapatkan dari e-business, yang diantaranya seperti:

1. Memperluas pasar, dengan e-business perusahaan atau pembisnis dapat memperluas pasarnya sehingga dapatmemasuki pasar nasional maupun internasional, sehingga pembisnis dapat menjangkau banyak pelanggan.

2. Menekan biaya telekomunikasi dan waktu transaksi serta penerimaan produk.

3. Konsumen dapat melihat barang, spesifikasi dan informasi lainnya melalui internet sehingga tidak perlu repot-repot harus mendatangi penjual.

4. Meningkatkan citra yang baik di mata para konsumen tentunya dengan pelayanan yang baik juga, sebab dengan media internet informasi dapat dengan cepat tersebar dan masih banyak lagi keuntungan yang lainnya

Adapun unsur-unsur pada e- business, yang diantaranya sebagai berikut:

1. Pelaku bisnis. Diantaranya seperti organisasi, produsen atau perusahaan, supplier, rekan bisnis, konsumen dll.

2. Alat, media atau sumber daya yang digunakan. Diantaranya seperti teknologi informasi dan komunikasi (Komputer, internet dll).

3. Kegiatan dan sasarannya. Diantaranya seperti kegiatan dan proses bisnis (pelayanan, penjualan dan transaksi) serta operasi bisnis utama.

4. Tujuannya. Diantaranya seperti komunikasi, koordinasi, pengolahan organisasi, transformasi proses bisnis dan berbagi informasi.

5. Beberapa keuntungan yang bisa di dapatkan. Diantaranya seperti pendekatan yang relatif aman, lebih fleksibel, efesien,peningkatan produktivitas, peningkatan keuntungan, bisnis yang terintegrasi dll.

\section{Penerapan E-business}

1. B2B (Business to Business). Merupakan transaksi bisnis yang dilakukan secara elektronik melalui jaringan internet, extranet, intranet, atau jaringan local.

2. B2C (Business to Consumer). Meliputi penjualan retail barang dan jasa kepada pembeli perorangan.Model bisnis dari B2C terjadi pada pelelangan, perusahaan penjual jasa, dan perusahaan retail online (e- tailing). B2C dapat membantu pengusaha kecil dan menengah karena dapat menyingkirkan perantara, menghemat biaya dan memberikan kemudahan, pertumbuhan bisnis lebih pesat daripada biaya yang harus dikeluarkan, dan adanya kebutuhan akan modal kerja yang lebih rendah dibandingkan dengan kasus bisnis konvensional sehingga harga dapat ditekan menjadi lebih murah.

3. C2C (Consumer to Consumer). Merupakan model bisnis dimana konsumen bertransaksilangsung dengan konsumen lain. Dalam pengimplementasian e-business, terdapat beberapa konsep atau strategi yang dapat diterapkan oleh perusahaan.

\section{Perusahaan Roti Ganda}

Roti Ganda adalah sepotong besar roti tawar yang dibelah dua lalu diolesi selai. Sebutan Roti Ganda berasal dari nama usaha roti legendaris yang dibuka sejak 1979 dan sudah bertahan hingga empat generasi di Pematang Siantar. Namanya Toko Roti Ganda, berlokasi di Jalan Kartini, Pematang Siantar, Sumatra Utara. Sebelumnya, Toko ini terletak di Jalan Sutomo.

Meskipun toko roti ini telah lama berdiri dan memiliki banyak pesaing sejenis di kota tersebut, namun masyarakat di Kota Pematangsiantar tetap menjadikan Toko Roti Ganda sebagai pilihan utama untuk membeli roti. Bahkan banyak perantau yang bekerja di luar kota menjadikan roti ini sebagai oleh - oleh khas dari kota Pematangsiantar. Hal - hal yang membuat pelanggan toko roti ini dapat loyal dalam membeli dan mengkonsumsi roti ini adalah kebersihan dan cita rasa yang terus di pertahankan oleh toko roti ini juga membuat masyarakat percaya dan loyal.

Maka dari itu pelanggan tetap percaya dengan kualitas dari roti ini karena toko roti ini tetap mempertahankannya. Setelah loyalitas pelanggan terbentuk aspek lain yang tidak kalah penting 
adalah membangun kepercayaan merek (brand trust) dari Toko Roti Ganda ini. Membangun merek yang kuat itu adalah salah satu modal yang kuat bagi sebuah usaha. Dengan meningkatkan kepercayaan terhadap merek (brand trust) maka sebuah usaha dapat terus eksis walaupun banyak pesaing sejenis yang baru merintis.

Setelah kepercayaan merek (brand trust) telah terbentuk, maka aktivitas untuk memilih merek yang sama akan meningkat. Oleh sebab itu, penting bagi sebuah usaha untuk membangun ekuitas merek yang kuat. Hal - hal yang dapat meningkatkan kepercayaan merek (brand trust) terhadap suatu produk adalah keyakinan dalam mengkonsumsi produlk dan konsistensi dalam mengkonsumsi merek yang sama. Apabila kepercayaan merek telah terbentuk dalam pola pikit konsumen maka itu dapat menambah nilai positif bagi sebuah usaha.

\section{METODE PENELITIAN}

Penelitian ini dilakukan dengan metode studi literatur. Studi literatur adalah metode mencari referensi teori dengan membaca berbagai sumber baik dari buku, jurnal, artikel, laporan penelitian, maupun situs - situs di internet. Studi literatur yang dilakukan harus berasal dari sumber - sumber yang relefan dan sesuai dengan permasalahan yang ditemukan dalam penelitian. Studi literatur ini bertujuan untuk memperkuat teori dalam menjelaskan mengenai suatu masalah dalam penelitian. Penelitian ini menggunakan jurnal - jurnal dan artikel mengenai pengolahan limbah plastik menjadi bahan bakar sebagai rujukan. Setelah membaca beberapa referensi atau rujukan yang digunakan, kemudian dapat disimpulkan hasil dari penelitian yang telah dilakukan sebelumnya mengenai pengolahan limbah plastik menjadi bahan bakar. Kesimpulan yang didapat kemudian dituangkan kembali ke dalam tulisan yang baru berdasarkan rujukan yang telah digunakan.

\section{HASIL DAN PEMBAHASAN}

Dalam proses perancangan Penerapan E-Business pada Toko Roti Ganda berbasis web dengan pendekatan CRM (Customer Relationship Management) diperlukan penjelasan atau teori yang dapat mendukung dan menunjang keberhasilan dalam pembuatan sistem informasi tersebut serta untuk menjelaskan kepada user bagaimana fungsi dan manfaat dari penerapan E-Business pada Toko Roti Ganda berbasis web dengan pendekatan CRM. Berikut adalah gambar dari aliran sistem informasi yang sedang berjalan.

Dengan adanya Penerapan E-business pada perusahaan roti ganda, maka akan memudahkan para konsumen untuk membeli roti ganda tersebut. Serta dengan penerapan ebusines pada perusahaan roti ganda dapat memajukan bisnis roti ganda.

Berdasarkan hasil penilian bahwa Toko roti Ganda yang telah menggunakan aplikasi dan sosial media memberikan dampak positif serta meningkatkan profit yang diperoleh terhadap kuliner yang dipasarkan serta masyarakat lebih mudah memesan produk denganmenggunakan sistem online. Keuntungan menggunakan e-business yaitu pertama memperluas pasar, dengan menggunakan e-business perusahaan atau juga pembisnis akan dapat memperluas pasarnya sehingga bisa memasuki pasar nasional atau bahkan internasional, sehinggapembisnis itu dapat menjangkau banyak pelanggan itu dimanapun iaberada.Kedua, menekan biaya telekomunikasi serta juga waktu transaksi dan juga penerimaan produk.Ketiga, Konsumen ini dapat melihat barang, spesifikasi serta informasi lainnya dengan melalui internet sehingga tidak perlu repot- repot untuk harus mendatangi penjual.Keempat, Meningkatkan citra yangbaik di mata para konsumen, tentunya haltersebut apabila dengan pelayanan yang baik juga, sebab dengan media internet informasi itu bisa dapat dengan cepat tersebar. 


\section{KESIMPULAN DAN SARAN}

Istilah E-business mengacu pada penggunaan internet untuk berdagang. Perusahaan yang tidak mau beralih ke teknologi ini, lambat laun akan kewalahan menghadapi era pasar terbuka nantinya. Dukungan teknologi informasi dan komunikasi mengembangkan cara baru dalam bertransaksi (e-commerce). Beberapa manfaat yang bisa di dapatkan dari e-business, yang diantaranya seperti: Memperluas pasar, dengan e-business perusahaan atau pembisnis dapat memperluas pasarnya sehingga dapatmemasuki pasar nasional maupun internasional, sehingga pembisnis dapat menjangkau banyak pelanggan.

Dalam pengimplementasian e-business, terdapat beberapa konsep atau strategi yang dapat diterapkan oleh perusahaan. Dalam proses perancangan Penerapan E-Business pada Toko Roti Ganda berbasis web dengan pendekatan CRM (Customer Relationship Management) diperlukan penjelasan atau teori yang dapat mendukung dan menunjang keberhasilan dalam pembuatan sistem informasi tersebut serta untuk menjelaskan kepada user bagaimana fungsi dan manfaat dari penerapan E-Business pada Toko Roti Ganda berbasis web dengan pendekatan CRM.

Dengan adanya Penerapan E-business pada perusahaan roti ganda, maka akan memudahkan para konsumen untuk membeli roti ganda tersebut.Berdasarkan hasil penilian bahwa Toko roti Ganda yang telah menggunakan aplikasi dan sosial media memberikan dampak positif serta meningkatkan profit yang diperoleh terhadap kuliner yang dipasarkan serta masyarakat lebih mudah memesan produk dengan menggunakan sistem online.

Kedua, menekan biaya telekomunikasi serta juga waktu transaksi dan juga penerimaan produk.Ketiga,Meningkatkan citra yang baik di mata para konsumen, tentunya hal tersebut apabila dengan pelayanan yang baik juga, sebab dengan media internet informasi itu bisa dapat dengan cepat tersebar.

\section{DAFTAR PUSTAKA}

Noerlina\& Siti Elda Hiererra, 2013.Penilaian Pemanfaatan Teknologi E-Business Pada Industri Umkm.Jurnal.Information Systems Department, School of Information Systems, Binus University. ComTech Vol.4 No. 2 Desember 2013: 1216-1224

Dewi Irmawati. 2011. Pemanfaatan E-commerce dalam dunia bisnis online. (http://www.academia.edu/download/36013991/PEMANFAATAN ECOMMERS DALAM DUNIA BISNIS.pdf)

https://ksmtour.com/pusat-oleh-oleh/oleh-oleh-khas-pematang-siantar/roti-ganda-legendaris-daripematang-siantar.html 